\title{
Therapy of Effective Progressive Muscle Relaxation to Reduce Insomnia in Elderly
}

\author{
Desi Natalia Trijayanti Idris, Kili Astarani \\ Institute of Health Science RS Baptis Kediri, Indonesia \\ idrisdede87@gmail.com
}

\begin{abstract}
Elderly experiencing problems sleeping disorders one of which is insomnia. One of the efforts to overcome insomnia is progressive muscle relaxation therapy. This study aims to analyze the effect of progressive muscle relaxation therapy on insomnia in the elderly. This research was designed using Pre Experimental, one group pre-test - post-test design. The number of subjects in this study were 14 respondents who met the inclusion criteria at the St. Yoseph Kediri Nursing Home. This research was taken using quota sampling. Data collected through observation and interviews before. Next, it is analyzed using the Wilcoxon Signed Rank Test. H1 is accepted, if $\mathrm{p}$ value $<\alpha(0.05)$ to determine the effect of progressive muscle relaxation therapy on insomnia in the elderly. There are 2 independent and dependent variables in this study. The independent variable of this study was progressive muscle relaxation therapy and the dependent variable was insomnia. The tool used in this study is a module for progressive muscle relaxation therapy exercises, insomnia questionnaire using the Insomnia Saverity Index (ISI) Instrument. This research was conducted during June July 2019 at the St. Yoseph Kediri Nursing Home. The results showed there was an effect of progressive muscle relaxation therapy with insomnia based on the Wilcoxon test $(\mathrm{p}=$ 0.004 ), and $\mathrm{z}$ score $=2.850$. Conclusion This study states that non-pharmacological therapy of progressive muscle relaxation therapy can be a nurse's independent action in providing nursing care to patients, especially in elderly patients who experience insomnia.
\end{abstract}

Keywords: Progressive muscle relaxation therapy, Insomnia, Elderly

Received August, 25, 2019; Revised September 22, 2019; Accepted October 20, 2019

(7) (2) STRADA Jurnal Ilmiah Kesehatan, its website, and the articles published there in are licensed under a Creative Commons Attribution-ShareAlike 4.0 International License. 


\section{STRADA Jurnal Ilmiah Kesehatan}

DOI: $10.30994 /$ sjik.v8i2.219

ISSN: 2252-3847 (print); 2614-350X (online)

Vol.8 No.2. November 2019. Page.165-171

\section{BACKGROUND}

The aging process is a process of slowly disappearing the ability of the network to repair itself or replace itself and maintain its normal function so that it cannot survive infection and repair the damage suffered (Bandiyah, 2009). Aging is not a disease but a process of decreased endurance in dealing with stressors from inside and outside the body. Problems that occur in the elderly include easy fall, fatigue, cardiovascular disorders, pain or discomfort, elimination disorders, visual acuity disorders, hearing loss, sleep disorders, easy itching (Nugroho, 2008). Sleep disorders that occur one of which is insomnia. Insomnia is one of the sleep disorders, if the need for sleep and rest is not met properly eating will affect health. While sleep is one of the basic human needs that occurs naturally and has physiological and psychological functions for the body's repair process. If someone does not get a good sleep it will cause damage to muscle and brain function because of inadequate sleep needs (Stanley, 2006). The age factor causes the elderly to face many limitations so that they need assistance to improve their social welfare (Samsudrajat, 2012). A good quality of life will bring the elderly to be able to live productively within their limitations. Conversely, a decrease in quality of life actually makes the elderly become unproductive humans, even dependent on the help of other parties. Decreased quality of life is partly due to sleep disturbances as a result of the aging process. and the most complained by the elderly. One of the causes of insomnia in the elderly is the lack of physical and mental activity throughout the day so they are still up all night (Maryam, 2008). The number of elderly people in Indonesia in 2012 was recorded at around 19 million (7.7 out of 245 million population). According to the central statistical projection (BPS) the number of elderly will continue to increase until it exceeds the amount of improvement in quality and life expectancy. While the number of elderly people in East Java in 2007 reached 11.14 million. About 60\% experience insomnia or difficulty falling asleep (Setyoadi, 2011). In 2013, May Dagita Sukma's research on giving milk before going to sleep increased the quantity of sleep in the elderly at the Anggrek Posyandu, Bangsal Village.

Increasing the elderly population is followed by various problems for the elderly themselves, this is caused by the aging process. Along with aging, let alone entering old age (elderly) various changes occur in the body. One of them is physiological and psychological changes in the elderly. Psychological changes in the elderly include: irritability, sadness, anxiety, loneliness and irritability from these changes can affect the sleep patterns of the elderly, where the elderly are not relaxed, too many thoughts so that sleep disturbance in the elderly in the elderly (insomnia) . This insomnia is the inability to sleep, interruptions during sleep, the existence of normal sleep behavior during sleep, or the timing of sleep episodes that do not fit. Complaints experienced by the elderly in their sleep patterns is that when the elderly have woken up in the middle of the night it is difficult to start sleeping again.

The impact of this sleep disorder if it occurs continuously will cause: depression, impaired ability to control yourself, reduced motor performance, an increase in accidents, impaired immune response, cardiovascular disease, diabetes, obesity (Vaughans, 2013). Besides the need for poor sleep in the elderly is able to cause waking during the day, someone with chronic insomnia can feel sleepy, tired, depressed, and anxious (Potter \& Perry, 2010). Conversely, if the need for sleep in the elderly can be overcome so that the elderly can get good sleep quality, the elderly can maintain mental, emotional, health, reduce stress on the lungs, cardiovascular, endocrine, and others (Hidayat, 2010). Management of insomnia can be divided into pharmacologically and non pharmacologically. Pharmacologically that is by giving sadative and hyponotic drugs, this type of drug is very effective in accelerating the 


\section{STRADA Jurnal Ilmiah Kesehatan}

DOI: $10.30994 /$ sjik.v8i2.219

achievement when starting to sleep, prolonging sleep, and reducing the frequency of waking up. However, these drugs cause negative effects, including leaving a residual effect of the drug, which is nausea and drowsiness during the day, and cause people with sleep disorders experience drug dependence. While non-pharmacological management does not cause side effects and can be done alone by the elderly to maintain their health. There are several nonpharmacological treatments for insomnia such as: progressive muscle relaxation, diaphragmatic breathing, imagery training, biofeedback, hypnosis (Miltenberger 2004). The cheapest non-pharmacological therapy to date, does not require imagination, perseverance or suggestion, no side effects, easy to do is progressive muscle relaxation. Progressive muscle relaxation is one technique to reduce muscle tension by a simple and systematic process in tensing a group of muscles and then relaxing them again (Setyoadi, 2011).

\section{OBJECTIVE}

This study aimed to analyze the effect of progressive muscle relaxation therapy on insomnia in the elderly.

\section{METHODS}

The design used is a pre-experimental research (one-group pre-post test design). The hallmark of this research is revealing a causal relationship by involving a group of subjects. Subject groups were observed before the intervention and then observed again after the intervention (Nursalam, 2016). The samples of this study were 14 elderly taken by sampling quota from 28 existing elderly. There are 2 independent and dependent variables in this study. The independent variable of this study was progressive muscle relaxation therapy and the dependent variable was insomnia. The tools used in this study were modules for progressive muscle relaxation therapy exercises, insomnia questionnaires using the Insomnia Saverity Index (ISI) Instrument and for blood pressure measured using a sphigmomanometer and recorded on an observation sheet. This research was conducted during June - July 2019 at the St. Yoseph Kediri Nursing Home. This research through a research ethics test before data collection. After the ethical test, the researcher submits a research permit to the research location and waits for the permit answer. The researcher conducted apperception with numerators, namely 5 students in taking data.

\section{RESULTS}

Table 1. Category of Insomnia in the Elderly Community of St. Yoseph Kediri Nursing Home in June-July $2019(\mathrm{n}=14)$

\begin{tabular}{lcccc}
\hline \multirow{2}{*}{ Category } & \multicolumn{2}{c}{ Before } & \multicolumn{2}{c}{ After } \\
\cline { 2 - 5 } & Amount & Percentage (\%) & Amount & Percentage (\%) \\
\hline No insomnia & 0 & 0 & 5 & 35,8 \\
\hline Mild Insomnia & 5 & 35,7 & 8 & 57,1 \\
\hline Moderate insomnia & 6 & 42,9 & 1 & 7,1 \\
\hline Severe insomnia & 3 & 21,4 & 0 & 0 \\
\hline Total & 14 & 100 & 14 & 100 \\
\hline
\end{tabular}

Based on table 1 it can be seen that before laughing therapy or progressive muscle relaxation therapy $100 \%$ of the elderly experience insomnia in both mild, moderate to severe categories 
and after therapy there is a decrease in insomnia from those in the moderate, mild categories and until there is no insomnia.

Table 2. Wilcoxon Statistical Test Results Signed Rank Test The Effect of Progressive Muscle Relaxation Therapy on Insomnia in the Elderly at the St. Joseph Wredha Nursing Home in June-July $2019(\mathrm{n}=14)$

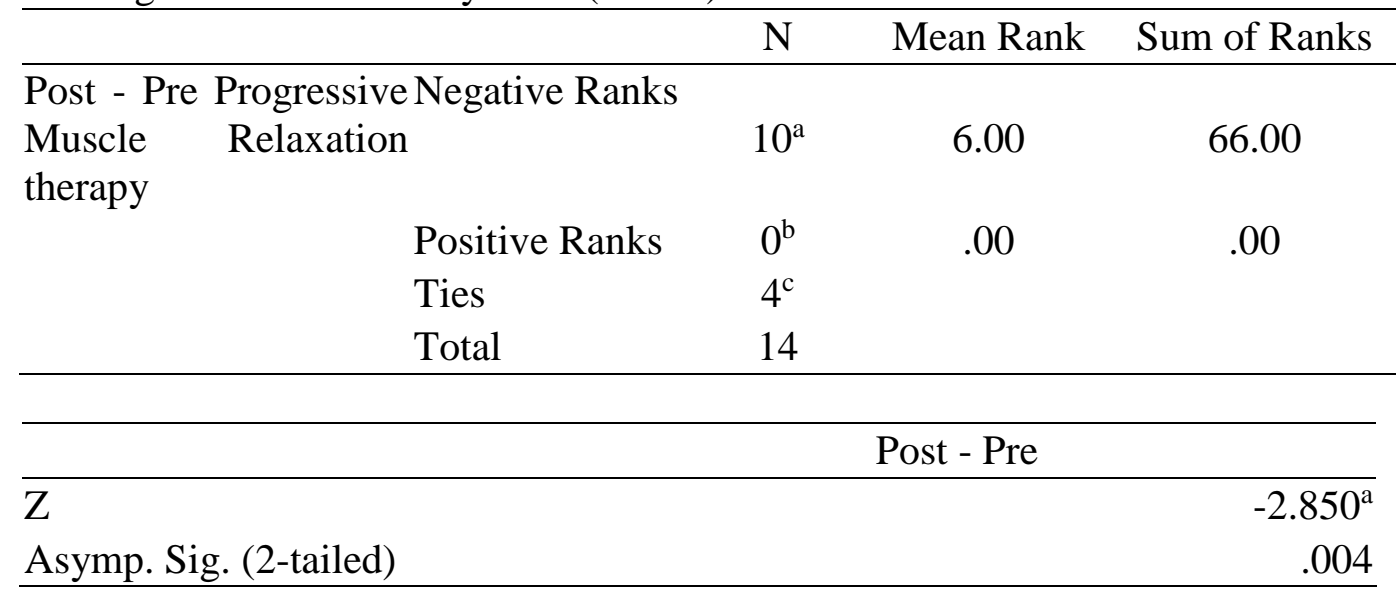

Based on table 2 the Wilcoxon Signed Rank Test statistic above the $\mathrm{Z}$ value of -2.850 with the significant level specified being $\alpha=0.05$ and the value of $p=0.004$, the results of the data set are $\mathrm{p}<0.05$ which means $\mathrm{H} 1$ is accepted, it can be concluded that there is an effect of progressive muscle relaxation therapy on insomnia in the elderly

\section{DISCUSSION}

\section{Insomnia Before Progressive muscle relaxation therapy is performed}

Elderly at the St. Joseph Wredha Orphanage before progressive muscle relaxation therapy for insomnia, all elderly people experience insomnia from both mild to severe categories. Theoretically, aging or aging is a condition that occurs in human life. Growing old is a natural process, which means someone has gone through three stages of life, namely children, adults, and old people. It was concluded that humans slowly experienced a decline in the structure and function of organs. Deterioration of the structure and function of organs in the elderly can affect the independence and health of the elderly (Nugroho, 2008). In this aging process the elderly experience problems that occur in the elderly including easy fall, fatigue, cardiovascular disorders, pain or discomfort, elimination disorders, visual acuity disorders, hearing loss, sleep disorders, easy itching (Nugroho, 2008). Sleep disturbance in the elderly is caused by: external (external) factors, such as a less calm environment, intrinsic factors, both organic and pycogenic. Organic moves (akatisia), and certain diseases that make you nervous. Psychogenic, for example depression, anxiety, stress, irritability, and anger that are not channeled (Nugroho, 2008). Sleep disorders that occur one of which is insomnia. Insomnia is a state of inability to get adequate sleep, both quality and quantity, with a state of sleep only briefly or insomnia (Hidayat, 2009). Causes of insomnia include: situational stress such as family, work, or school problems, jet lag, illness, loss of loved ones (Widya, 2010).

The elderly physiologically experience changes in sleep patterns, even to the point of insomnia. Changes that occur in the brain from the molecular level, to the structure and function of brain organs. As a result of these changes there will be a decrease in blood 


\section{STRADA Jurnal Ilmiah Kesehatan}

DOI: $10.30994 /$ sjik.v8i2.219

ISSN: 2252-3847 (print); 2614-350X (online)

Vol.8 No.2. November 2019. Page.165-171

circulation to the brain in certain areas. As a result of the above process, the phenomenon that arises is structural and physiological changes, such as: insomnia, behavior disorders, sexual disorders, and cognitive disorders. In addition, it can also be caused because REM sleep episodes tend to shorten there are progressive stages of sleep NREM 3 and Based on the results of insomnia research experienced by the most dominant respondents namely sleep quality that changes. The total amount of sleep does not change with age, however, the quality of sleep seems to change in most elderly (Potter \& Perry, 2010). The increase in the elderly population is followed by various problems for the elderly themselves, this is caused by the aging process. Reducing the number of hours of sleep is not a problem if the elderly themselves feel a good quality of sleep because with good sleep quality even though only two hours can restore the function of the body and brain. In addition to the things above, sleep disturbance (insomnia) in the elderly is also caused by biological and psychological factors. Biological factors such as the presence of certain diseases that cause a person can not sleep well. Psychological factors can be anxiety, psychological stress, fear and emotional tension together with other physical changes. In the elderly, generally the homeostatic urge to sleep first decreases, followed by a circadian rhythm drive to awake. In addition to the above, the rhythmic circadian sleep-wake of the elderly is also often disrupted, biological hours are shorter and the sleep phase is more advanced. Hormones are secreted during deep sleep, especially at night, so a decrease in hormone levels will make it difficult for older people to maintain sleep. The changes that occur in the elderly are a normal thing. In the degeneration process that occurs in the elderly, effective sleep time will be increasingly reduced. Therefore, respondents who have lived a long time, especially over 60 years, are more difficult to get quality and quantity sleep. This psychological problem is often related to poor sleep habits. If the condition continues, the fear of not being able to sleep can cause waking during the day, someone with chronic insomnia can feel sleepy, tired, depressed, and anxious. Psychological problems that can cause insomnia between them are anxiety, depression, and stress, high levels of stress can also inhibit the effects of recovery of growth hormones that help the making of new cells. Stress can be caused by various problems that cause fear, anxiety, stress, trauma, and the like. Therefore by watching television the elderly feel there is entertainment and for a moment to divert attention to the problem at hand.

\section{Insomnia After Progressive muscle relaxation therapy in the elderly}

Elderly at the St. Joseph Wredha Orphanage after progressive muscle relaxation therapy for insomnia, there are a small proportion of elderly people experiencing insomnia.

Theoretically, Insomnia is the inability to get enough quality and quantity of sleep. Insomnia is known as insomnia. A problem that often arises is the difficulty to start and maintain sleep (Kupfer \& Reynolds 2012). During aging, sleep patterns undergo distinctive changes, which differentiate young people from those changes including sluggish sleep, disruption in the early hours of the morning, and an increase in the number of naps as well as the amount of time spent sleeping deeper in decline (Mickey and Patricia, 2006). Management of insomnia can be divided into pharmacologically and non-pharmacologically. Pharmacologically that is by administering sadative and hyponotic drugs, this type of drug is very effective in accelerating the achievement of when it starts sleeping, prolonging sleep, and reducing the frequency of waking up. However, these drugs cause negative effects, including leave a residual effect of the drug, which is nausea and drowsiness during the day, and cause people with sleep disorders to experience drug dependence. While non-pharmacological management does not cause side effects and can be done by the elderly themselves to 


\section{STRADA Jurnal Ilmiah Kesehatan}

DOI: $10.30994 /$ sjik.v8i2.219

ISSN: 2252-3847 (print); 2614-350X (online)

Vol.8 No.2. November 2019. Page.165-171

maintain their health. There are several non-pharmacological treatments for insomnia such as: progressive muscle relaxation, diaphragmatic breathing, imagery training, biofeedback, hypnosis (Miltenberger 2004). One example of physical exercise is progressive muscle relaxation therapy. Progressive muscle relaxation therapy is deep muscle relaxation therapy that does not require imagination, perseverance, or suggestion (Setyoadi, 2011). Progressive relaxation is one way of relaxation techniques that combines deep breathing exercises and a series of contractions and certain muscle relaxation (Kustanti and Widodo 2008 in Setyoadi, 2011). Professive muscle relaxation therapy is carried out for twenty to thirty minutes with fifteen movements each movement is carried out for 10 seconds (Setyoadi, 2011). Progressive muscle relaxation therapy is useful to overcome insomnia, depression, fatigue, irritability, spasms, muscles, phobias, mild, mild stuttering (Setyoadi, 2011). Things that need to be considered during exercise include: Don't overexert muscle tension because it can hurt yourself, it takes about 20-50 seconds to make the muscles relax, pay attention to body position, be more comfortable with eyes closed, avoid standing position, tense the muscle group twice the tension, do the right part of the body twice, then the left side twice, check whether the client is really relaxed, continuously giving instructions, giving instructions not too fast and not too slow (Setyoadi, 2011).

Based on the results of the study, after progressive muscle relaxation therapy there were 14 respondents who experienced changes in sleep patterns and insomnia, more changes occurred at the time of starting to sleep, the elderly who usually start sleeping more than 30 minutes after being done progressive muscle relaxation therapy elderly can start sleep less than 30 minutes, the elderly who usually wake up 3-4 times at night after doing progressive muscle relaxation therapy elderly wake up at night only 1-2 times, the elderly also experience changes in sleep for 30 minutes to 1 hour, upon awakening in the morning the elderly feel refreshed than before because before bed they do good activities for fitness. Progressive muscle relaxation therapy is a deep muscle relaxation therapy that does not require imagination, perseverance, or suggestion. Indications of Progressive Muscle Relaxation Therapy are: the elderly who experience sleep disorders (insomnia), the elderly who often experience stress, the elderly who experience anxiety, the elderly who experience depression. Contraindications Progressive Muscle Relaxation Therapy is: elderly who have limited mobility, such as not moving their body, lanisa who has bed rest. The stages for progressive muscle relaxation therapy are 15 movements. Movement 1: intended to train the hand muscles; Movement 2: shown to train the back of the hand muscles; Movement 3: shown to train the biceps (large muscles at the top of the base of the arm); Movement 4: shown to train the shoulder muscles to relax; movements 5 and 6: shown to relax facial muscles (such as the muscles of the forehead, eyes, jaw and mouth); Movement 7: intended to relax the tension experienced by the jaw muscles; movement 8: shown to relax the muscles around the mouth; Movement 9: shown to relax the front and back of the neck muscles; Movement 10: shown to train the front neck muscles; Movement 11: shown to train the back muscles; movement 12: intended to relax the chest muscles; Movement 13: shown to train abdominal muscles; Movement 14-15: shown to train leg muscles (such as thighs and calves). Progressive muscle relaxation therapy is carried out for 3 times a week for 20-30 minutes. Progressive muscle relaxation therapy is useful for forming physical conditions (muscle strength, flexibility, and balance), refreshing the mind, and can overcome insomnia, this is because support from the family plays an important role in encouraging respondents' interest or willingness to take part in progressive muscle relaxation therapy activities. The family can be a powerful motivator for the elderly who are always willing to accompany 


\section{STRADA Jurnal Ilmiah Kesehatan}

DOI: $10.30994 /$ sjik.v8i2.219

ISSN: 2252-3847 (print); 2614-350X (online)

Vol.8 No.2. November 2019. Page.165-171

them, reminding respondents if they forget the progressive muscle relaxation therapy movement. This makes the respondent motivated to continue doing progressive muscle relaxation therapy routinely, so that insomnia experienced by the respondent can be reduced.

\section{CONCLUSION}

Elderly at the St. Joseph Wredha Orphanage before progressive muscle relaxation therapy is found for all elderly experiencing insomnia. Progressive muscle relaxation therapy for insomnia has been shown to reduce the incidence of insomnia in the elderly significantly or significantly to changes in insomnia in the elderly at the St. Joseph Wredha Nursing Home with a value of $\mathrm{P}=0.004$.

\section{ACKNOWLEDGE}

Thanks to the Ministry of Research, Technology, and Higher Education Republic of Indonesia for the support for this research (Ristekdikti).

\section{REFERENCES}

Bandiyah. (2009). Usia Dan Keperawatan Gerontik. Jogjakarta: Nuha Medika.

Hidayat. (2009). Pengantar Kebutuhan Dasar Manusia Aplikasi dan Konsep Keperawatan. Jakarta: Salemba Medika.

Kupfer \& Reynolds. (2012). Gangguan Tidur Pada Usia Lanjut. Jakarta: Balai Penerbit FKUI.

Maryam. (2008). Mengenal Usia Lanjut Dan Perawatanya. Jakarta: Salemba Medika.

Mickey dan patricia, (2006). Keperawatan Gerontik. Edisi 2 cetakan pertama Jakarta : EGC

Miltenberger. (2004). Relaksasi. Availableonlineathttp//www.eworld-indonesia.com (diakses 2 Februari 2008)

Nugroho. (2008).Keperawatan Gerontik dan Geriatrik. Jakarta: Buku Kedokteran EGC.

Perry dan Potter, (2009).Buku Ajar Fundamental Keperawatan Konsep Proses dan Praktik, Volume 2 Edisi 4. Jakarta: Buku Kedokteran EGC.

Stanley, M. (2006). Buku Ajar Keperawatan Gerontik. Jakarta: EGC

Setiadi, (2007). Konsep dan Penerapan Metodologi Penelitian Ilmu Keperawatan. Jogjakarta: Graha Ilmu.

Setyoadi. (2011). Terapi Modalitas Keperawatan Pada Klien Psikogeriatrik. Jakarta: Salemba Medika.

Vaughans, Benita. W. (2013).Keperawatan Dasar. Yogyakarta : Rapha publishing Widya. (2010). Mengatasi Insomnia. Jogjakarta. Kata Hati 